DOI: 10.1515/ausfm-2017-0003

\title{
The Flux of Transmigrant Identities in Thomas Arslan's Brothers and Sisters
}

\author{
Anna Bátori \\ Babeş-Bolyai University (Cluj-Napoca) \\ E-mail: anna.batori@gmx.net
}

\begin{abstract}
The paper investigates Brothers and Sisters (GeschwisterKardeşler, 1995), the first piece of Thomas Arslan's Berlin-trilogy. While putting the film into the socio-historical context of the newly united German Republic, the study aims to highlight the characters' struggle and constant shift between their Turkish and German identity. Through the narrative and textual analysis of Brothers and Sisters, the paper reveals the visual forms of social exclusion and concludes that in Arslan's film, the characters bear with no social identity but various stages of identification, which keep them in an in-between, insecure position.
\end{abstract}

Keywords: Turkish-German cinema, Thomas Arslan, transmigrant identity, multicultural society, accented cinema.

\section{Introduction}

Describing the migration policy of Germany as a complete failure at the conference of the Christian Democratic Union (CDU) in Potsdam in 2010, Angela Merkel claimed that the multicultural idea of society has failed, and the harmonious coexistence of diverse nations in Europe remains impossible (Evans 2010). With its second largest immigrant population in Europe (see: Constant, Nottmeyer and Zimmermann 2012), Germany currently raises the third generation of Turkish diaspora that make up almost half of the immigrant community of the country (see Cox 2011). Because, according to Merkel, the Turkish minority is incapable of integrating into the German society, they form a segregated class within the social structure of the country. With the current wave of European mass-migration and the role of Germany in it, Merkel's arguments raise serious questions about the future, identity and role of the continent. How has migration changed the life of the German majority and how does it affect the Turkish sub-culture? How does the 
German-Turkish diaspora identify itself and what is the approach of the motherland, Turkey to the phenomenon? How does the Turkish minority represent itself and what diegetic-contextual forms do we find when it comes to visual embodiment?

Embedded in the framework of new realism in German cinema (Reimann 2006) - the second wave of filmic reflection of the Turkish minority - the present study examines Brothers and Sisters (Geschwister-Kardeşler, 1995), the first and lesser known piece of the German-Turkish director Thomas Arslan's Berlin Trilogy. With the attempt to answer the questions posed above, the paper focuses on the self-identification of Turkish transmigrants, and discusses the dual, transient identity (Hall 1996) that the characters occupy in the film.

\section{The Turkish Question in the Reunified Germany}

As Verena Stolcke (1995) puts it, opposed to the old discourse of racial inferiority, the new "contemporary cultural fundamentalism" prevalent in Western Europe $(1995,4)$ "assumes a set of symmetric counterconcepts, that of the foreigner, the stranger, the alien as opposed to the national, the citizen," which eventually "legitimates the exclusion of foreigners, strangers" (1995, 5-7). In the German context, the essentialist, romantic idea of nationhood - built upon the trinity of a shared language, culture and identity (Minden 2011) - is conceived as a homogeneous unifier shaped by history, passed on from generation to generation, which leaves no space for any other national concept. For this reason, the pejorative, exclusionist labels that have been used for Turks living in Germany, not only strengthen the outsider position of the minority, but assumes their ever-present transitional position. ${ }^{1}$ As White states, "Germans have redefined the Turks to meet their own economic and political needs. [...] Fremdarbeiter (foreign workers), and Gastarbeiter (guest workers) are terms fallen out of use,

1 As it erased the very East German and West German identities, the re-union of the German Democratic Republic and West Germany brought a radical change and the negative feelings towards settled foreign workers flared up after the reunification in 1990. The definition and search for a new identity involved not only the rethinking of the concept of identity and history, but also meant the facing of the consequences that the sudden demographic, economic, political and social changes have caused. Interestingly, the state of animosity arising between the West German society and the despised Easterners (Ossies) negotiated the post-socialist society the same way the Turkish foreign workers were contextualized in the capitalist structure. As Jenny B. White (1997) points out, the tension caused by the national reunification was targeted at the Turkish community. The immigrants, who belonged neither to the East nor to the West, and were outsiders to the German community, became the enemy (Harnisch et al. 1998). Fearing for their jobs, East Germans protested the foreign workforce with equal vehemence, which put the Turks in an in-between position attacked by both sides (White 1997; Räthzel 2006). 
replaced in part by Ausländer (foreigners) or ausländische Arbeitnehmer (foreign employees). A contemporary, more politically correct nomenclature is Migranten (migrants) or ausländische Mitbürger (foreign co-citizens), never Immigranten, as that would imply the right to remain. Turks, as the Other, have always been considered ausländer, and some argue that Germans consider Turks among the most inferior groups of foreigners" $(1997,761)$.

The Turkish migrant and diasporic communities (Naficy 2001) thus constitute a separate, marginalized layer, drifting between acceptance and social exclusion in the German community (Kolinsky 1996, Baser 2016). On the other hand, they are also excluded from the Turkish national rhetoric and context that, because of not belonging to the Turkish motherland per se, refers to them as a "germanized" (Almancilar) group (Baser 2016). Not belonging to Turkey, nor being part of the national German discourse, Turks living in Germany are trapped in an inbetween transnational space of "cultural liminality, chastised in both Germany and Turkey for being too foreign" (Vanderlinden 1991, 51).

In a cultural-linguistic context, this in-between, fluid identity position of the Turkish minority has been often expressed and mediated through various literary terms that point out the transitional state of the individual. In his poem, Double Man (Doppelmann), Zafer Şenocak, a widely-published German-Turkish poet describes this position as carrying two moving worlds within, that are separated by his tongue (Şenocak 1984). Similarly, in her poem In-between (Dazwischen), Alev Tekinay describes her position as being stuck on an imaginary train that commutes between Turkey and Germany, and which does not provide her with a real sense of home (Tekinay 1990). The travel, constant movement and changing states of belonging are thus expressed by a great variety of rhetorical tropes, such as the above-mentioned train metaphor of dualism that highlights the rootedness of the subject (Yalçın-Heckmann 2005; Yegenoglu 2005). The most telling rhetorical figure that expresses this in-between, Almancilar-Ausländer position is the image of the bridge ${ }^{2}$ that, while resting on neither bank, connects the two cultures ${ }^{3}$ (McGowan 2007).

2 In a recent manifesto, the well-known bridge metaphor has been challenged by Adelson (2005) who, because of its motionless, fixed association, rejects the inbetween-paradigm. As she emphasizes, "the cultural fable we like to tell about migrants 'between two worlds' differs with increasing frequency from stories that literary texts born of migration actually set into motion at the turn to the twenty-first century." There is a need "for more critical imagination brought to bear on component elements, textual structures, and cultural relations that figure in the literature of migration in the volatile decade of the 1990" $(2005,5)$.

3 Nevfel Cumart's poem Zwei Welten (Two Worlds) depicts this transnational state of being as follows: "Between/two/worlds/amidst/unending/solitude/I would like/to be a bridge/but I can/ 


\section{Transnationalist Discourse}

Due to the fact that, as the above-mentioned Turkish-German situation illustrates, globalisation created a multilocal diasporic culture, in which previous discourses about national identity and citizenship have radically transformed (Vertovec and Kohen 1999), the post-colonial scholarship investigating the social-cultural transformations in the continent and beyond has been focusing on the various concepts of transnationalism (Kaya 2012). As Schiller et al. (1992) put it, "Our earlier conceptions of immigrant and migrant no longer suffice. The word immigrant evokes images [...] of the uprooted, the abandonment of old patterns and the painful learning of a new language and culture. Now, a new kind of migrating population is emerging, composed of those whose networks, activities and patterns of life encompass both their host and home societies. [...] We call this new conceptualization, 'transnationalism' and describe the new type of migrants as transmigrants" (2004, 213).

The new-born, essentialist rhetoric gave way to post-national expressions and terms such as post-national (Habermas 2001), transnational (Bauböck 2010), flexible (Ong 1999) or hybrid identity (Smith and Leavy 2008), which are based on a new, post-structuralist concept of the nation. ${ }^{4}$ Stuart Hall (1990) also discusses postmodern and hybrid identities, arguing that identity is always a fluid, rather than a stable condition. As he argues, "we should think [...] of identity as a 'production' which is never complete, always in process, and always constituted within, not outside, representation. [...] Cultural identity [...] is a matter of 'becoming' as well as 'being.' It belongs to the future as much as to the past and [...] undergo[es] constant transformation" (Hall 1990, 224-225).

Hall argues that, because the postmodern social landscape is ever-changing, the new subject shall be described in terms of identification rather than identity. In his other study, Hall (1996) explains that this new, postmodern individual is historically, and not biologically defined, and "assumes different identities at different times, identities which are not unified around a coherent 'self'” (Hall 1996, 598). Although for Hall, "the fully unified, completed, secure and coherent identity is a fantasy" $(1996,598)$ and is continuously constructed by various

hardly gain a foothold/on the one bank/on the other/I am losing my footing/more and more/the bridge is breaking/threatens/ to tear me apart/in the middle" (Cumart 1993, trans. Marquis, M. and Furtun, M.).

4 Also, in the contemporary flow of migration, new forms of legal and normative status and identities were formed, such as multiple nationals, ethnizens (external quasi-citizenship) and denizens (residential quasi-citizenship). See Bauböck 2007 and Kaya 2012. 
narratives, he does not equate this fluid state with the complete lack of identity. What happens, if the subject cannot identify himself with any cultural context and becomes unable to respond to the cultural-historical interpellation, or on the contrary, takes on a multi-layered process of identification whereby the subject itself, disappears or gets stuck in an in-between position?

As Andrea Reimann (2006) points out, because the transnational GermanTurkish subjects have not been allowed to participate in the national and social discourse of the host country, they are permanently relegated to the role of the subaltern (Spivak 1988), while they continuously attempt to develop a strong ethnic community (Kaya 2012). Their dual, rhizomic identity (Deleuze and Guattari 1987) therefore masks a lack of absolute identification, for they are constantly put in the position of the excluded from both the German and Turkish sides. Therefore, we can argue that, in the pre-2000 German discourse and cultural practice - where the Turkish self-representation and its German contextualization is an under-researched and negotiated area - the subaltern subject assumes a transnational, hybrid identity that, as an ever-changing fragmented and fluid state, offers no identification, and therefore no identity for the migrant. In this way, the subject itself creates its own segregationist identity in the very space of the ethnic community that he belongs to. The unique question raised by postmodern hybridization is, as to what extent is the subject able to live with their own fragmented, conflicted and contradictory identity? Also, how does he commute between the various (lack of) identities?

\section{The Two Waves of German-Turkish Cinema}

Answering the question posed above requires a detailed exploration of representation (Hall 1996; Stam and Spence 1983). According to the film theorist Hamid Naficy (2001), the contextual and diegetic layer of films can allude to the migrant and diasporic experience of the subject, be that the filmmaker himself or the displaced individual on screen. His term "accented cinema" is a form of aesthetic response of exiled, deterritorialized directors to the diasporic, exilic and postcolonial ways of living. These filmmakers maintain a special connection to their homeland, they memorialize it "by fetishizing it in the form of cathected sounds, images, and chronotopes" $(2001,12)$ that Naficy defines as "accented style” $(2001,22)$. This aesthetic approach contains visual markers of homeland and the past, such as landscapes, letters and photographs, that define collective and individual identities. Accented films also use multiple languages and/or 
accented pronunciation, while having extensive titling on screen to translate dialogues $(2001,16-39)$. Moreover, the contextual layer of these productions entails real or imaginary travels, be that a metaphoric journey of identity, or a physical movement of the individual $(2001,33)$.

When it comes to the spatial-temporal context of accented films, Naficy borrows Mikhail Bahtin's concept of chronotope and distinguishes between open, closed and transitional-transnational space-time configurations that are embedded in the mise-en-scène, filming and narrative structure $(2001,153)$. Open chronotopes, he argues, use open, external spaces, such as landscapes, while emphasizing the openness by mobile framing and long shots. On the other hand, the closed form is built on closed, claustrophobic settings, such as prisons and, by using static framing and tight shots, accentuates the restricted movements of the characters. His third category, thirdspace chronotope, refers to transitional sites such as borders and airports, and buses and trains that all emphasize diverse, fluid spatiotemporal zones $(2001,154)$. Chronotopes, "polyphony and heteroglossia [...] [thus all] localize and locate the films as texts of cultural and temporal difference" $(2001,25)$, and create a transnational form of artistic practice that expresses the filmmaker's very identity.

Naficy's chronotopes correspond to two distinct waves of Turkish-German accented cinema. The first tendency (1960-80) uses the closed form and emphasizes imprisonment, oppression and claustrophobia, which arises from small, crowded living spaces, and domestic violence against Turkish women (Göktürk 2000; Reimann 2006; Burns 2006). Films of the first wave, such as Tevfik Baser's $40 \mathrm{~m} 2$ Deutschland (40 m2 Germany, 1986) and Abschied vom falschen Paradies (Farewell to a False Paradise, 1988), Helma Sanders-Brahms's Shirin's Hochzeit (Shirin's Wedding, 1975), operate with the narratives of victimization and concentrate on the oppressed role of females within the confines of the Turkish patriarchal immigrant society (Göktürk 2002; Berghahn 2011). Reimann calls these productions "ius soli films" for they "are about relations across communal divisions, which then proceed to reveal the tensions beneath the appearance of family harmony and togetherness and the fragility of accepted notions of ethnic identity" $(2006,58)$, in a period heavily influenced by the discourse of the new immigration law and double citizenship (Burns 2006).

The second, and more complex wave of Turkish-German cinema (1993-2004) offers "a more differentiated picture of the Turkish diasporic community. [...] [It illustrates] hyphenated identities [...] as a source of mutual cultural enrichment" (Berghahn 2011, 240), and, instead of the fixed, strict female-male roles, poses 
questions of belonging and identity. The second wave is thus a politically more aware trend, which, as Reimann puts it, displays a certain kind of social realism (Reimann 2006) "as response to the efforts of post-wall cinema to normalize and affirm German national identity and [...] to the tradition of realism in cinema" $(2006,19)$. Social realism in this case also assumes the realistic portrayal of the urban environment that the protagonists are enclosed into.

This new generation of films includes, among others, Fatih Akin's Kurz und schmerzlos (Short Sharp Shock, 1998) and Gegen die Wand (Head-On, 2004), Kutluğ Ataman's Lola und Bilidikid (Lola and Billi the Kid, 1999); Yüksel Yavuz's Mein Vater, der Gastarbeiter (My Father, the Guest Worker, 1994) and Aprilkinder (April Children, 1998), Imset Elci’s Dögun - Die Heirat (Dögun, the Wedding, 1993) and Thomas Arslan's Geschwister (Brothers and Sisters, 1995) and Dealer (1999). These young filmmakers operate with open chronotopes set in Turkish urban neighbourhoods and, instead of nostalgic longing that was characteristic of the first wave, their stories are permeated by pessimism and utter hopelessness. The protagonists, who stagnate in Gemany without the promise of a better future, are usually young characters who end up in prison (Dealer), die (Short Sharp Shock) or, as strengthening their outsider position, are forced to end the relationship with their German girlfriend (Reimann 2006). Thus, instead of the "cinema of the affected" (Burns 2006) and its migrant, victimized and male-dominant Turkish identities, the second generation reckons with the stereotypical portrayal of Turks and touches upon contemporary sensitive, political topics that aim to a better description of the situation of the Turkish diaspora, their transmigrant identity and in-between position, while offering an up-to-date image of the dysfunctional, non-homogenous German host society (Burns 2007; Reimann 2006; Cox 2011).

\section{Brothers and Sisters}

Born in 1962 in Braunschweig, Germany to Turkish migrant parents, Thomas Arslan - one of the most prominent members of the second generation of Turkish accented cinema - experienced the transmigrant, diasporic state at a very early age. During his high school studies, he spent four years in Ankara, and then moved back to Germany to attend the German Film and Television Academy (CFFB) in Berlin, graduating in 1992.

His first feature film, Brothers and Sisters is often referred to as the first piece of his Berlin-trilogy, followed by Dealer in 1999 and Der schöne Tag (A Fine Day) in 2000. These films are all set in Kreuzberg, Berlin and reflect the personal 
experiences of Arslan (Burns 2007a). One of the main preoccupations of the German-Turkish director was to break with the ties of stereotypical representation of the first wave of accented cinema and capture the true lives of the minority: "I consider this self-imposed obligation to operate with representative characters to be a dangerous matter. There are enough of these representative figures in the media such as the Turkish greengrocer, who at the same time stands for an entire culture. In many films that often amounts to the usual stereotypes such as 'for or against the headscarf' and 'for or against forced marriage.' To that extent my film is rather untypical of one particular image of the Turks" (Arslan, quoted by Burns 2007a, 371).

Arslan's Brothers and Sisters follows the life of three siblings and their everyday lives in Kreuzberg, Berlin. Leyla (Serpil Turhan), Ahmed (Savaş Yurderi) and Erol (Tamer Yiğit) were born to a German mother and a Turkish father, and have each a different mindset and view about the world and their very situation in it.

The story begins with the eldest sibling, Erol's draft notice letter from the Turkish army. Not having a job, and future prospects in Germany, Erol decides to join the military. His choice triggers a series of conflicts within the family, that lead to secrets and tensions coming to surface. The younger brother Ahmed who is the most educated and level-headed among the three siblings - thinks of Erol's plans as idiocy, and disapproves his brother's idea of joining the army. It is however not only the eldest son who rebels against his very situation in Kreuzberg. The seventeen-year-old family member Leyla, who is kept on a short leash by her father, tries to break out of the domestic prison and live her life as an average teenager. However, her constant fight against the patriarchic family structure fails. Eventually, after violent conflicts within the family structure, Erol leaves Germany, while the two other siblings continue with their lives in Kreuzberg.

The main conflict of Brothers and Sisters is the constant clash of the German and Turkish identity within Erol, Ahmed and Leyla. While the two younger siblings accept the surrounding German environment and social context, Erol rejects his German identity and identifies himself as Turk. After getting his draft notice and having an argument with his mother about whether to go or stay in Berlin, he argues that, because he has a Turkish passport, he must join the army. Although his decision can be negotiated as a patriotic gesture, his perceived Turkishness is based more on economic, rather than nationalist reasons. Erol has dropped out of school, has no profession and no job, and lives from suspicious, illegal trades and businesses. During the years, he had also accumulated a huge debt and he is now constantly pushed for payment. When crossing the streets of Kreuzberg, he has to 
hide in doorways and alleys for not being spotted on, so that he can escape the confrontation with his lenders. For these reasons, joining the Turkish army seems to be his only way out of the hopeless financial situation and from the unsafe position he occupies within the Turkish-German gangland of Kreuzberg.

Although Erol constantly stresses his position as belonging to Turkey, his Turkish identity is far from stable as it first seems. His mother tounge, and his language of communication is German and, although he argues that he speaks Turkish, he barely uses it throughout the film. Erol interacts with his brother and Turkish environment in German, for which he is constantly attacked by his Turkish friends. Being half German, half Turkish, Erol is an absolute outsider in Kreuzberg. His fellows criticize him for not knowing Turkish, while he is also made fun for not speaking German properly.

Erol's only answer to his in-between, misfit situation is verbal and physical aggression, whereby he hopes to be accepted by the Turkish community. Resonating with the stereotypical, patriarchal representation of Turks in the first wave of the Turkish-German accented cinema, the eldest brother takes on the role of the aggressive, testosterone-driven male in the narrative. First, he attacks his brother for not speaking Turkish with his friends - which Erol himself does not do either - and then accuses Ahmed for being ashamed of having a Turkish father and acting German. Later, as if feeling his outsider position in Kreuzberg, Erol gets more and more suspicious about his environment and more and more frustrated about his financial situation and failed integration into the German society. While having dinner in a kebab-restaurant, he gets paranoid about being stared at by others eating at the same place. His friends try to chill him down, however, his only reaction to the situation is physical abuse. First, he beats up two German-looking boys that, according to him, harmed one of their Turkish friends. By the end of the film, his anger gets out of control and he beats up an innocent boy on the street for coming too close to him. Eventually, Erol's fustration culminates in hitting his own, beloved brother. Since, out of the three siblings, it is Ahmed who identifies himself most with the German context - a point which I will discuss later - this gesture is Erol's absolute turn towards his Turkish self. Interestingly, the only way for the eldest sibling to be accepted by the Turkish minority, and to prove that he belongs there, is his transformation into an agressive male.

In this regard, the representation of Turks in the film of Arslan does not differ from the narratives of victimization. Although it gets a psychological layer that alludes to the economic insecurity of the characters within the German society, 
Erol, as well as his father, are depicted as aggressive, dangerous males that suppress their environment. It must be emphasized however that, in contrast to the first wave, the identification with Turkey is not a deliberate decision, but an answer to the growing social insecurity and lack of respect that the male protagonists face. As the enforcer of patriarchy and the head of the family, the taxi-driver father faces difficulties with supporting his family, while his authority and decision-making role is constantly questioned by the female characters in the narratives. Leyla's self-confident, provocative style of communication and the strong, decisive role of the German wife in the mini-apparatus leave the father in a subjected, humiliated position, which he answers with verbal and physical abuse against the family members. He slaps his daughter for not showing enough respect towards him, and has fights with his wife for standing by Leyla. Confronted by his wife for hitting their daughter, he answers that he will leave to Turkey for good anyways, thus echoing his superfluous role within the family structure. As the situation suggests, his home country is his safe place where, unlike in his family in Berlin, his behaviour would be fully accepted and his role as a Turkish man, absolutely respected. Turkey thus automatically becomes equivalent of a male-centred, aggressive world, which also explains the transformation of Erol. Mimicking his father - and getting close to his future home - the eldest sibling slowly becomes a dominant male figure, feared for his aggressive gestures, but respected for his decision to join the army. His turn, however, does not presuppose any kind of identification. In the end of the film, Erol still speaks German and, while the others dance, he sits alone at the table at a Turkish wedding. Eventually, illustrating his in-between position and lack of identification within the narrative, Arslan portrays the eldest sibling in a thirdspace (Naficy 2001): the final scene of the film shows him at the airport as he is being checked in for his flight to Istanbul.

While in Brothers and Sisters it is Erol who aspires the most to become a fully respected member of the Kreuzbergian society, his younger brother and sister are less connected to their Turkish roots. Ahmed is more interested in living a social life that involves rap music, girls and hanging out with friends. He also does not have any comments when it comes to debates on Turkish heritage and/ or speaking Turkish. Similarly, Leyla has less connection with the country of his father. Although she is forced into the role of the protected and vulnerable subaltern by her father, she makes constant attempts to reckon with this female role. She often sleeps over Sevim (Mariam El Awad), her best friend's house, and goes out in the city while dreaming about having her own flat after she turns 18. 
On the other hand, however, Leyla dates a Turkish boy and all her friends come from a Turkish background. Also, unlike Erol, she sometimes switches to Turkish when talking to Sevim. The character of Leyla thus stands for the coexsistence of the Turkish and German world. The conflict between the two identities in Leyla is illustrated through the relationship with her boyfriend, Cem (Erhan Emre). Although the boy manifests everything that the Turkish diaspora would expect from the young girl, Cem is the least masculine character in the narrative. Opposite to the very patriarchal and testosterone-driven figures of Erol and his father, the young boy lets Leyla pay for her cinema ticket and takes on the subordinated - often humiliated - role during their conversations. His inferior role is also emphasized by his physical representation in the narrative. Cem is shorter than Leyla and Sevim, and he is often portrayed in frontal medium shots standing next to his girlfriend, whereby the height difference becomes even more evident. Thus, while at first sight, Leyla fulfils the requirements that his father and the Turkish diaspora have against her, the young girl protests against her subordinated position by choosing someone who is the absolute opposite of the character of her father and the figure of the stereotypical Turk in accented narratives. Ironically however, the choice of the young girl strongly resembles with the figure of her father so far as she opts for a weaker male who can be easily influenced by a German female. In this way, Cem assumes the role of the castrated male, while Leyla struggles with a hybrid identity that constantly shifts her between the German and Turkish self.

While Erol looks at himself as Turk, Ahmed takes on the most German identity in the narrative. Although he only hangs out with Turkish friends, the younger brother has a German girlfriend and he is seemingly attracted to fair-skinned, blonde German women. Sevim, for instance, seems to be attracted to Ahmed, however, the boy only talks to German girls at an underground party. Not being interested in speaking Turkish, or taking part in the illegal activities of the Turkish diaspora gang, Ahmed is an absolute misfit in the Kreuzbergian context. His outsider position is also emphasized by his looks. While Erol is dark-skinned, and has black, curly hair and unshaved skin, Ahmed has dark blond hair and, opposed to his brother's large, black leather jacket, he wears colourful, lighter, ordinary clothes. The identity of the brothers is thus further expressed by their physiognomy that stresses the flux between their Turkish or German self [Fig. 1]. 


\section{Germany, the Police State (?)}

Nevertheless, Arslan has often emphasized his very intention to veer away from the victimized narratives of the first Turkish-German wave, Brothers and Sisters depicts the Turkish community subordinated to the German one. This can be best seen in a scene where Erol, Ahmed and his Turkish friends are being scanned by the German police that line them up and violently push the young men against a pool table. While their belongings are being checked, the Turkish boys are aggressively told to remain in silence and only speak when asked, which they accept without any kind of verbal or physical resistance. It is clear that the German policemen treat them as offenders and, while they thoroughly frisk the suspects and examine their official documents, they not only humiliate the young boys, but also destroy some of their belongings. The subordinated position of the boys is also emphasized by their spatial representation. The German police hung upon the figures of the boys who, with their head lowered and facing the pool table, are portrayed as oppressed standing with their back to the police force [Fig. 2]. The two interrogators frame the group and enclose them into a suffocating position, thus emphasizing their absolute power over the boys. Having been ensured that the Turkish boys do not possess any drugs, the police then leave the table. While the dishevelled boys silently dress up, we see the two policemen arresting another group of teenagers in the background.

Although Arslan makes it clear that the scanning of the boys has been a misunderstanding, the whole scene and the reaction of the group after the accident, provides the spectator with a very clear power structure that describes the Turkish-German situation. When after the humiliating scene, Ufuk (Bilge Bingül), a friend of Ahmed and Erol, expresses his wish to join the German police, the group attacks him by stating that the institution is based on spying and attacking innocent Turks - which is justified by the violent police scene. Interestingly, none of the friends has concerns about Erol joining the Turkish army. However, when it comes to Ufuk entering the police academy, the friends turn away from him, so that he eventually leaves the scene.

\section{Arslan's Pitbull Analogy}

It must be emphasized that the portrayal of the German society is completely absent from Brothers and Sisters, and it is only the appearance of the two policemen that represents the German structure in the narrative. Still, through 
various metaphors, Arslan makes obvious attempts to mirror the subordinated role of the Turks. In a scene, for instance, he illustrates the impossibility of one's self-expression through the relationship-analogy of a pitbull and its owner who slowly build trust towards each other.

Joining Tayfun (Bülent Akil), Hassan (Mohamed Khalil) and Ufuk in a doorway in the streets of Kreuzberg, Erol enquires about the dog of Hassan [Fig. 3]. While the elder brother thinks that the pitbull is cute and he himself would like to have one, Ufuk argues that the dog looks like a pig, what is more, he is dangerous too, for he has attacked one of their friends the other week. Hassan goes on arguing that they are not dangerous at all, it is only that one has to win the trust of the animal. As an example, he states that one must sleep with the dog for getting familiar with the feeling. Ufuk ironically claims that Hassan is out of his mind and the pitbull would just rip his throat in his sleep. Despite his scepticism, Hassan stands by his opinion and argues that a pitbull would never hurt a person that has absolute trust in him. Ufuk strongly disagrees with the opinion of Hassan and argues that pitbulls should never be trusted. Their fight then gets interrupted by Erol who asks about the name of the dog that completely confuses the two young men. At first, Hassan does not understand the question and asks whose name he wants to know. Laughing about the confusion of his friend, Erol answers that he asked the name of the dog, the subject of the whole conversation. As if having been talking about something else, Hassan gets even more confused, but eventually understands the question.

Clearly, the conversation of Hassan and Ufuk highlights the tension between the German society and the Turkish minority within it. Hassan possesses a seemingly stable Turkish identity in the film, while Ufuk assumes a more German standpoint, with his very aim to join the police of the state. Hassan, on the other hand, criticizes Erol for his German roots, and tends to switch to Turkish during the verbal interactions with friends. In the dialogue of Hassan and Ufuk, the dog, Rocky - the metaphorical Turk, whose trust needs to be won - is the alter-ego of Hassan, and the whole Turkish minority at the same time. Having a stronger Turkish identity, Erol supports the idea of having a pitbull, while his brother Ahmed is less inclined to participate in the conversation. He only adds that he does not like dogs in general, and listens to the conversation in absolute silence. Ufuk, on the other hand, who most openly sympathizes with the German side, attacks Hassan for putting others in danger by having a pitbull. To summarize, Arslan's pitbull-metaphor mirrors the very identities of the characters of Brothers and Sisters, and highlights the importance and lack of trust in the relationship of the Turkish diaspora and the German host society. Similar to the police scene, Arslan puts the Turks in a victim- 
position, suggesting that the lack of understanding, trust and care generates an overly false picture of the Turkish diaspora - the pitbulls - who are thought to be wild and dangerous, yet they only need time to show their real, friendly side.

\section{Conclusion}

The outsider position of the Turkish protagonists is further emphasized by their representation on the streets of Kreuzberg. The closed form that characterized the Turkish-German cinema of the 1970s, gives way to an apparently open form based on the illustration of deserted and dirty streets. The walls in Kreuzberg are covered by graffiti, while the pavements are brimmed with autumn leaves that, together with the grey, brown and black colours that Arslan uses, give the outer scenes a suffocating atmosphere. Moreover, the protagonists are depicted as constantly moving - being on their way from A to B - that supports the displaced position of the characters and highlights the transmigrant, fluid identity they possess. Kreuzberg is also often depicted from a semi-subjective point of view of the protagonists, thus framing them from behind [Fig 4]. In this way, Kreuzberg is seen as framed by the back of Erol and his brother that creates the impression of a constant observer that follows and spies upon the boys. Consequently, the open formula suggests a place of confinement. Whether it is the gloomy streets of Kreuzberg, or the discoloured interior of the home or Erol and Ahmed that portrays a dysfunctional family model, the characters are represented as enclosed in the very space of Kreuzberg. In this way, the closed formula that characterized the first wave of accented cinema, has transformed into a larger - but still enclosed - scene that encompasses the streets of the city that imprison the characters.

Whether it is about physical movement, or identification with the Turkish and German roles, Ahmed, Erol and Leyla are portrayed as constantly drifting in the narrative. On the one hand, the mobile framing - that accentuates the position of the protagonists as being constantly watched, and long shots help Arslan to establish the very diasporic environment that encloses the protagonists. On the other hand, however, the siblings possess a constantly shifting, rhizomic, hybridtransmigrant identity that resonates with their physical movements, while offering various ways of identification with either the Turkish or the German side. Because of the fluid identities that characterize the siblings, Ahmed, Leyla and Erol often seem to get confused and lost in the process of identification. They attempt to assume a Turkish or German identity, but constantly fail to identify with solely one role, which pushes them into an in-between, insecure inner state. 


\section{References}

Adelson, Leslie A. 2005. The Turkish Turn in Contemporary German Literature. New York: Palgrave Macmillan.

Baser, Bahar. 2016. Diasporas and Homeland Conflicts. A Comparative Perspective. London and New York: Routledge.

Bauböck, Rainer. 2010. Cold Constellations and Hot Identities: Political Theory Questions about Transnationalism and Diaspora. In Diaspora and Transnationalism: Concepts, Theories and Methods, eds. Rainer Bauböck and Thomas Faist, 295-322. Amsterdam: Amsterdam University Press.

Bauböck, Reiner. 2007. Stakeholder Citizenship and Transnational Political Participation: a Normative Evaluation of External Voting. Fordham Law Review, vol. 75: 2393-2447. Amsterdam University Press.

Berghahn, Daniela. 2006. East German Cinema after Unification. In German Cinema Since Unification, ed. David Clarke, 79-105. London: Continuum.

Berghahn, Daniela. 2011. "Seeing everything with different eyes.” The Diasporic Optic in Fatih Akin's Head-On (2004). In New Directions in German Cinema, eds. Paul Cooke and Chris Homewood, 239-257. London: I.B. Tauris.

Burns, Rob. 2006. Turkish-German Cinema: from Cultural Resistance to Transnational Cinema? In German Cinema Since Unification, ed. David Clark, 127-151. London: Continuum.

Burns, Rob. 2007a. The Politics of Cultural Representation: Turkish-German Encounters. German Politics vol. 16, no. 3: 358-378.

Burns, Rob. 2007b. Towards a Cinema of Cultural Hybridity: Turkish-German Filmmakers and the Representation of Alterity. Journal of Contemporary Central and Eastern Europe vol. 15, no. 1: 3-24.

Constant, Amelie; Olga Nottmeyer and Klaus Zimmermann. 2012. Cultural Integration in Germany. In Cultural Integration of Immigrants in Europe, ed. Yann Algan, Alberto Bisin, Alan Manning and Thierry Verdier, 69-125. Oxford: Oxford University Press.

Cox, Ayça Tunç. 2011. Three Generations of Turkish Filmmakers in Germany: Three different narratives. Turkish Studies vol. 12, no. 1: 115-127.

Cumart, Nevfel. 1993. Das Lachen bewahren: Gedichte aus den Jahren 1983 bis 1993 [Poems, 1983-1993]. Düsseldorf: Grupello.

Deleuze, Gilles and Félix Guattari. 1987. A Thousand Plateaus: Capitalism and Schizophrenia. Somerset: Bookcraft. 
Evans, Stephen. 2010. Merkel says German multicultural society has failed. BBC News. http://www.bbc.co.uk/news/world-europe-11559451. Last accessed 23. 01. 2017.

Göktürk, Deniz. 2000. Turkish Women on German Streets: Closure and Exposure in Transnational Cinema. In Spaces in European Cinema, ed. Mytro Konstantarakos, 74-77. Portland: Intellect Books.

Göktürk, Deniz. 2002. Beyond Paternalism: Turkish German Traffic in Cinema. In The German Cinema Book, eds. Tim Bergfelder, Erica Carter and Deniz Göktürk, 248-257. London: British Film Institute.

Habermas, Jürgen. 2001. The Postnational Constellation: Political Essays (Studies in Contemporary German Social Thought). Cambridge: MIT Press.

Hall, Stuart. 1990. Cultural Identity and Diaspora. In Identity: Community, Culture, Difference, ed. J. Rutherford, 222-237. London: Lawrence \& Wishart. Hall, Stuart. 1996. Critical Dialogues in Cultural Studies. New York: Routledge. Harnisch, Antje; Anne-Marie Stokes and Friedemann Weidauer, eds. 1998. Fringe Voices. An Anthology of Minority Writing in the Federal Republic of Germany. Oxford, New York: Berghahn.

Kaya, Ayhan. 2012. Transnational Citizenship: German-Turks and Liberalizing Citizenship Regimes. Citizenship Studies vol. 16, no 2: 153-172.

Kolinsky, Eva. 1996. Non-German Minorities in Contemporary German Society. Turkish Culture in German Society Today, ed. David Horrocks, 71-111. Oxford: Berghahn Books.

McGowan, Moray. 2007. Turkish-German Fiction since the mid 1990s. In Contemporary German Fiction, ed. Stuart Taberner, 196-215. Cambridge: Cambridge University Press.

Minden, Michael. 2011. Modern German Literature. Cambridge: Polity Press.

Naficy, Hamid. 2001. An Accented Cinema: Exilic and Diasporic Filmmaking. New Jersey: Princeton University Press.

Räthzel, Nora. 2006. Aussiedler and Ausländer: Transforming German National Identity. In Transformations of the New Germany, ed. Ruth A. Starkman, 157179. New York: Palgrave.

Reimann, Andrea. 2006. Growing up in Postwall Germany: Situating TurkishGerman Cinema as New Realism. Chicago: University of Illinois.

Schiller, Nina Glick; Linda Basch and Cristina Blanc-Szanton. 1992. Transnationalism: A New Analytic Framework for Understanding Migration. Annals of the New York Academy of Sciences vol. 645: 1-24. 
Şenocak, Zafer. 1984. Doppelmann. In Türken Deutscher Sprache: Bericht, Erzählungen, Gedichte [Turkish German Language: Reports, Stories, Poems], ed. I. Ackermann, 39. München: Deutscher Taschenbuch Verlag.

Smith, Keri E. Iyall and Patricia Leavy, eds. 2008. Hybrid Identities. Theoretical and Empirical Examinations. Leiden: IDC Publishers.

Spivak, Gayatri Chakravorty. 1988. “Can the Subaltern Speak?”. In Marxism and the Interpretation of Culture, eds. Cary Nelson and Lawrence Grossberg, 270313. Urbana: University of Illinois.

Stam, Robert and Louise Spence. 1983. Colonialism, Racism and Representation. Screen vol. 24, no 2: 2-20.

Stolcke, Verena. 1995. Talking Culture: New Boundaries, New Rhetorics of Exclusion in Europe. Current Anthropology vol. 36, no. 1: 1-24.

Tekinay, Alev. 1990. Deutschprüfung [German exam]. Frankfurt am Main: Brandes \& Apsel Verlag.

Vanderlinden, Lisa K. 2009. East in West? Turkish Migrants and the Conception of the Ethnic Other in Germany. In Assisting Reproduction, Testing Genes. Global Encounters with New Biotechnologies, eds. Daphna Birenbaum-Carmeli and Maria C. Inhorn, 29-61. New York, Oxford: Berghahn Books.

Vertovec, Steven and Robin Cohen, eds. 1999. Migration, Diasporas and Transnationalism. Cheltenham: Edward Elgar Publishing.

White, Jenny B. 1997. Turks in New Germany. American Anthropologist vol. 99, no. 4: 754-769.

Yalcim-Heckmann, Lale. 2005. Are Fireworks Islamic? Towards an Undertanding of Turkish Migrants and Islam in Germany. In Syncretism/Anti-syncretism. The Politics of Religious Synthesis, eds. Charles Steward and Rosalind Shaw, 169-185. London: Routledge.

Yegenoglu, Meyda. 2005. From Guest Worker to Hybrid Immigrant: Changing Themes of German-Turkish Literature. In Migrant Cartographies: New Cultural and Literary Spaces in Post-Colonial Europe, eds. Sandra Ponzanesi and Daniela Merolla, 137-151. Oxford: Lexington Books. 


\section{List of Figures}

Figure 1. Thomas Arslan: Brothers and Sisters (Geschwister-Kardesler, 1995): the brothers' physiognomy expressing a flux in-between Turkish and German identity.

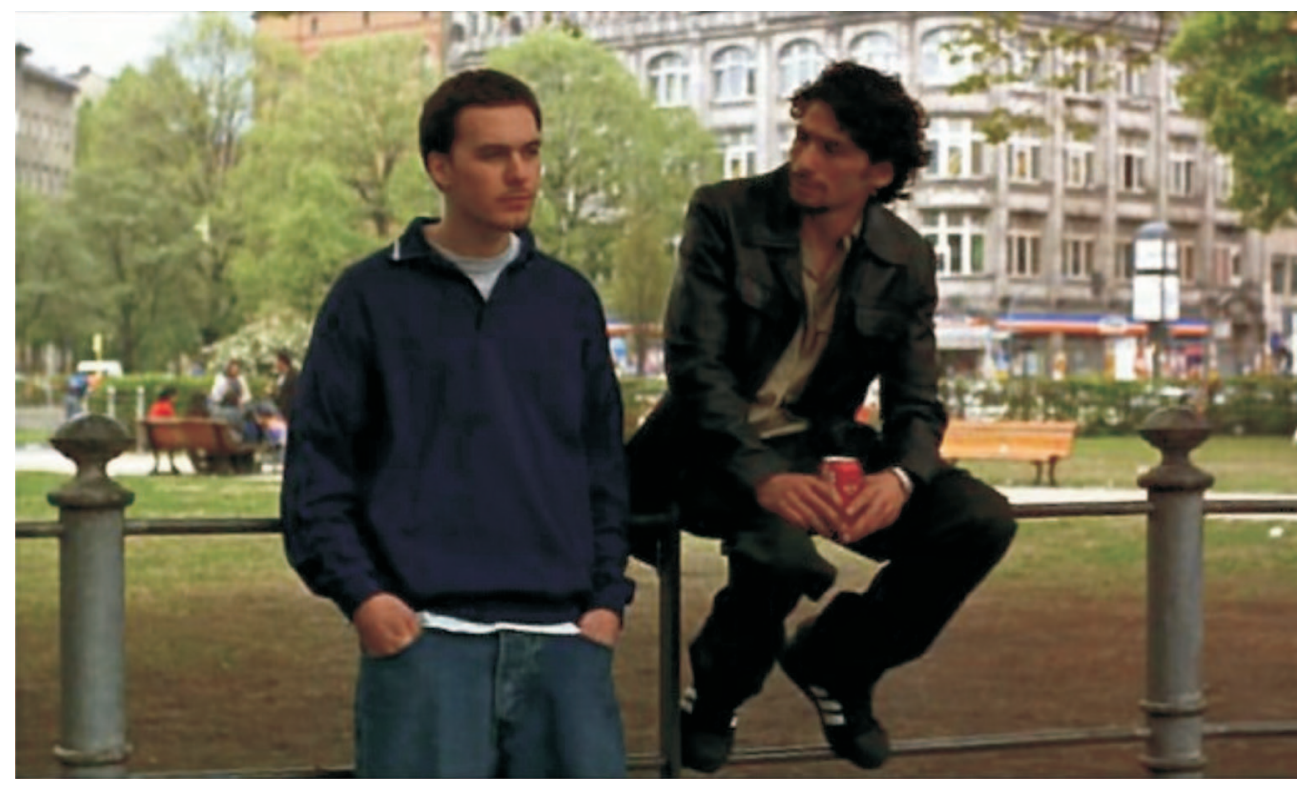

Figure 2. The subordinate position of the boys emphasized in the scene with the police.

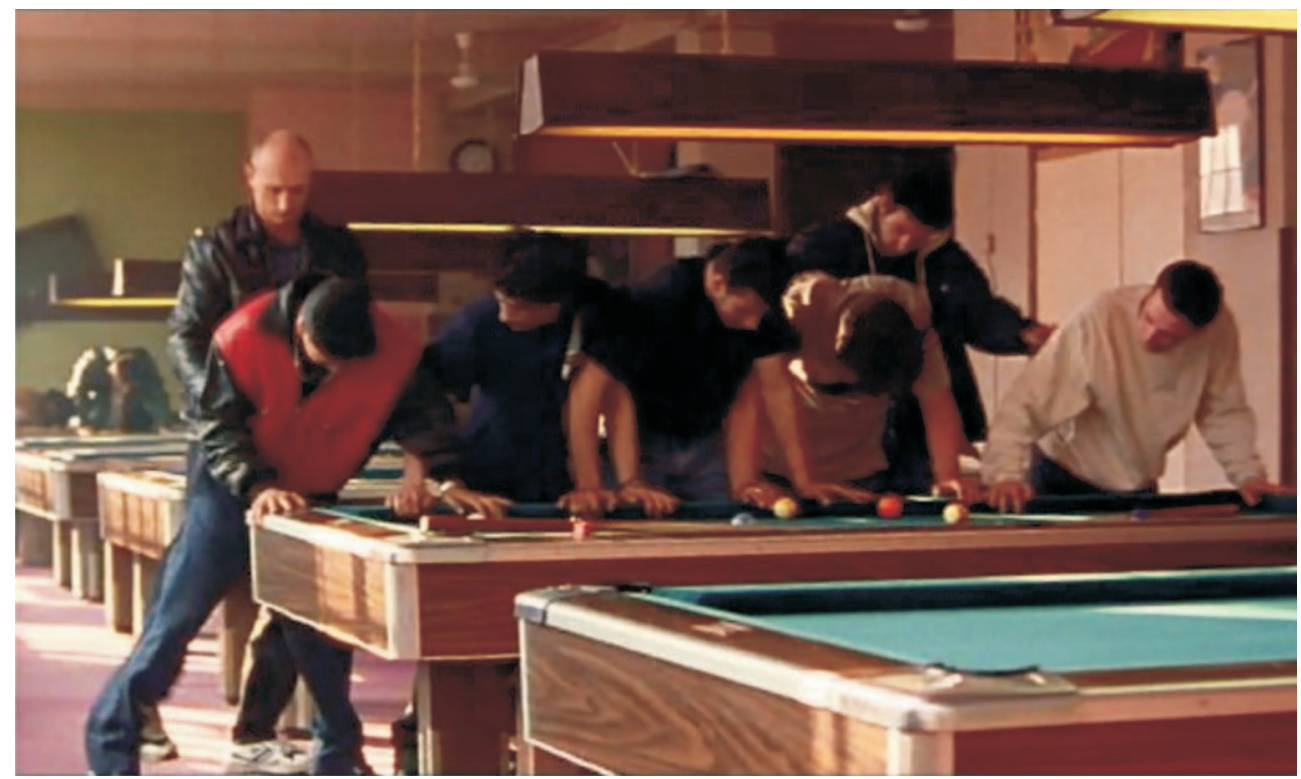


Figure 3. The argument about the dog staged in the doorway.

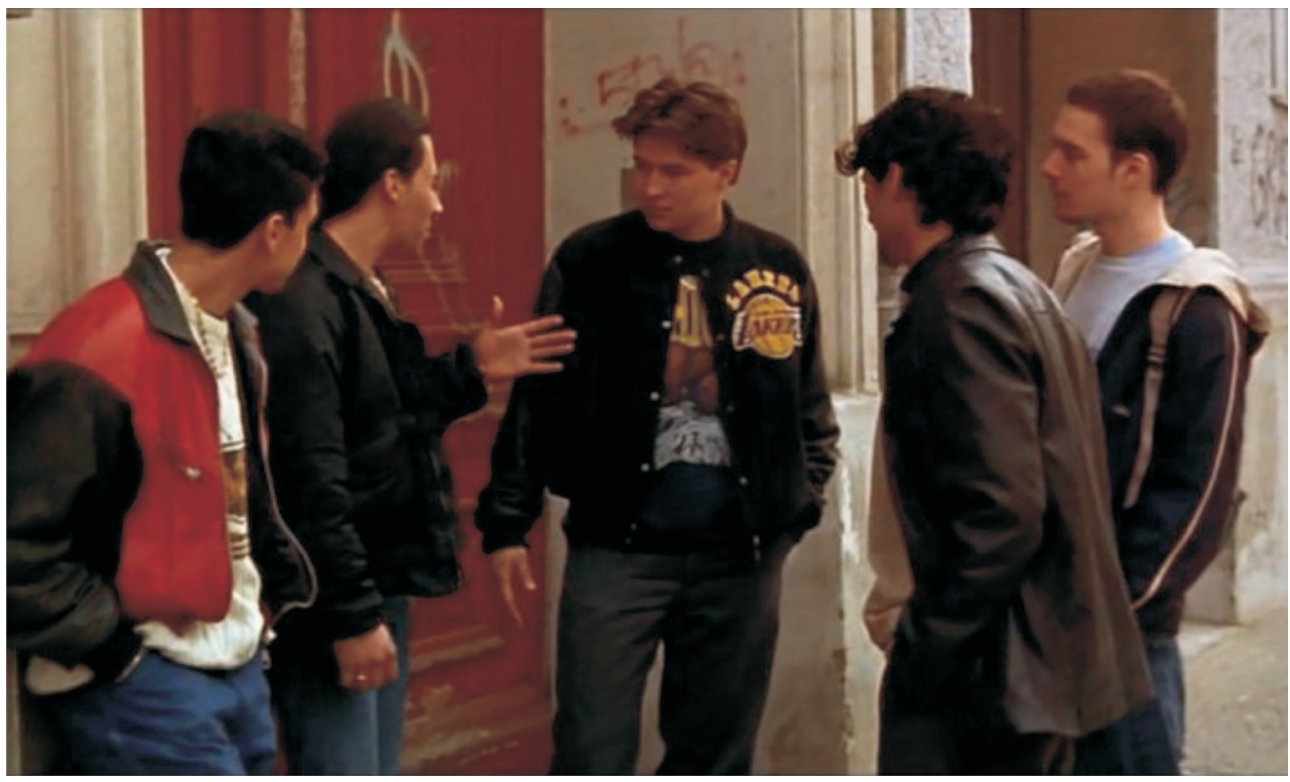

Figure 4. The protagonists are depicted as constantly moving, often framed from behind, shown from a semi-subjective point of view.

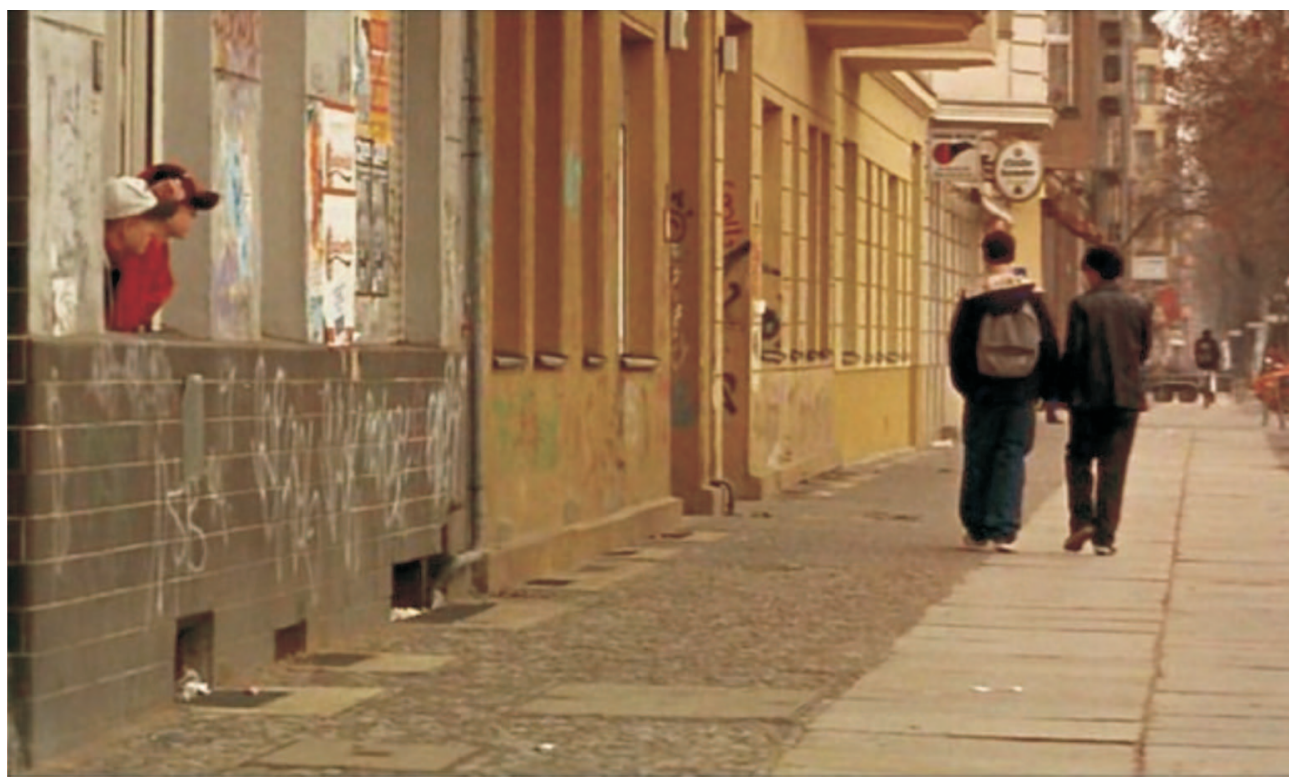

